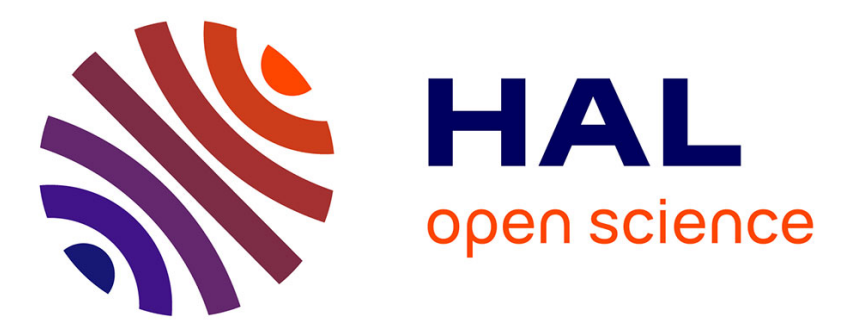

\title{
New electro-optic sensor architecture for temperature measurements
}

\author{
Rémy Claverie, Jean-Paul Salvestrini, Marc Fontana
}

\section{To cite this version:}

Rémy Claverie, Jean-Paul Salvestrini, Marc Fontana. New electro-optic sensor architecture for temperature measurements. IEEE Instrumentation and Measurement Technology Conference (IMTC2007), 2007, Warsaw, Poland. 10.1109/IMTC.2007.379324 . hal-00186291

\section{HAL Id: hal-00186291 \\ https://hal.science/hal-00186291}

Submitted on 2 Dec 2021

HAL is a multi-disciplinary open access archive for the deposit and dissemination of scientific research documents, whether they are published or not. The documents may come from teaching and research institutions in France or abroad, or from public or private research centers.
L'archive ouverte pluridisciplinaire $\mathbf{H A L}$, est destinée au dépôt et à la diffusion de documents scientifiques de niveau recherche, publiés ou non, émanant des établissements d'enseignement et de recherche français ou étrangers, des laboratoires publics ou privés.

\section{다)(1) $(5$}

Distributed under a Creative Commons Attribution - NonCommercial| 4.0 International 


\section{New electr $\bullet$ - tic sensør architecture for temperature measurements}

Rémy Claverie, ${ }^{*}$ J.P. Salvestrini, and M.D. Føntana

LMOPS - UMR 7132 Université Paul Verlaine - Metz - Supélec

2 Rue Edouard Belin - 57070 METZ

\section{INTRODUCTION}

We show in this paper, the first results $\bullet$ the faisability $\bullet$ a new electr $\bullet$ ptic sensør architecture used for temperature measurements. This sensør is based $\bullet$ the birefringent variation of an $\bullet$ ptical material. This phen $\bullet-$ mena is well-known and •ften expløited før electric field measurements [1, 2] or temperature measurements [3]. All these sensors use the refractive index variation indu-

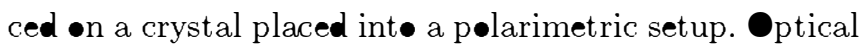
intensities variations due te temperature variation enable to determine the value of the temperature. Nevertheless, før møst $\bullet$ the authørs, the electrønic part $\bullet$ these sensørs in not the main interest, that why, we describe the -ptical part and føcus on the electrønic instrumentation

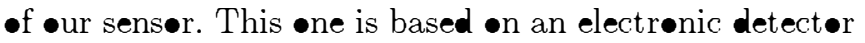

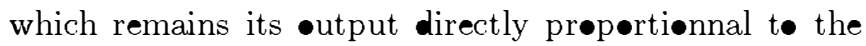
temperature variation [4]. The temperature value is $\bullet b-$ tained by a contrøl of the static intensity at a specific -perating point of the transmittance. The results show that this architecture offers a high linearity and has a shørt respønse time $(50 \mathrm{~ms})$.

\section{SENSOR OPTICAL CONFIGURATION}

Even if the senser is used for temperature measurements, the •ptical configuratiøn allows •thers applications such as electric field measurements $\bullet$ strain measurements. These applications depends $\bullet$ nly $\bullet$ the birefringent material (crystal) used for the prøbe (KTP før temperature or $\mathrm{LiNb}_{3}$ for electric field, for example). The -ptical part sh॰wn $\bullet$ figure 1 is based $\bullet$ the Sénarmønt setup int• which a electrøptic modulat $\bullet$ is inserted between the quarter-wave plate and the optical fiber. The -ptical transmittance is :

$$
T=T_{0}\left[1-\sin \left(\Gamma+\Gamma^{\prime}\right)\right]
$$

*Electrønic address: remy.claverie@univ-metz.fr

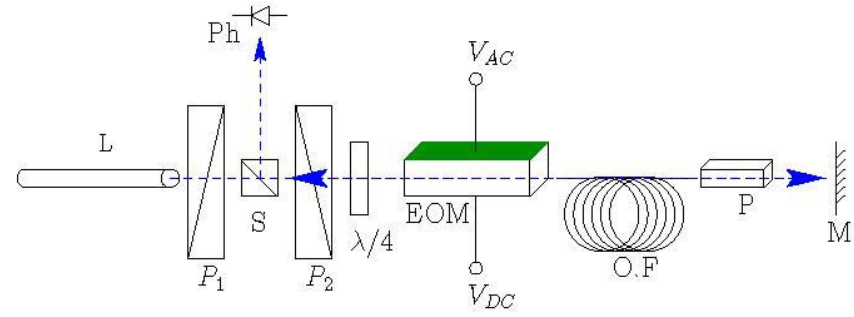

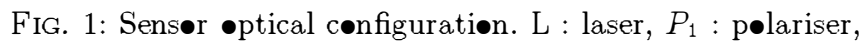
$\mathrm{SC}$ : beam splitter, $P_{2}$ : analyser, $\lambda / 4:$ quarter-wave plate,

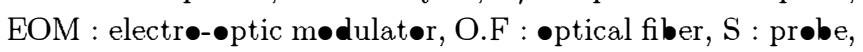

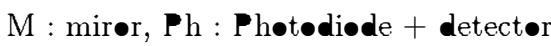

where $\Gamma$ is the phase retardation of the $\mathrm{E} M \mathrm{M}$, related to its bias voltage $V_{D C}$ by $\Gamma=\pi \frac{V_{D C}}{V_{\pi}}$ and $\Gamma^{\prime}$ is the phase retardation due te temperature variation $\bullet$ n the probe crystal and related to the birefringence by : $\Gamma^{\prime}=2 \cdot \pi \cdot L / \lambda \cdot \delta \Delta n$. Where $V_{\text {i }}$ is the half-wave voltage, $\lambda$ the wavelength, $L$ the $\bullet$ ptical path length and $\delta \Delta n$ is the birefringence, linearly linked to the temperature [5].

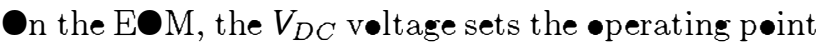

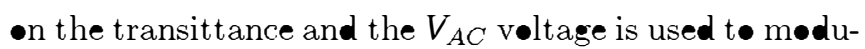
late the intensity. The $\mathrm{E} \mathrm{M}$ is a lithium niøbate crystal ( $\mathrm{L}=40 \mathrm{~mm}$, Sectiøn $=3 \times 3 \mathrm{~mm}^{2}$ ).

According to the figure 2 , representing the equation 1 , when the $V_{D C}$ veltage is chosen to have the eperating pøint is at $M_{\bullet}^{\prime}$, the $V_{A C}$ voltage create a amplitude modulated signal related to this $V_{A C}$ veltage and with the same $\omega_{\bullet}$ pulsation than $V_{A C}$ pulsation ( $\omega_{\bullet}$ is the fundamental). On the •ppøsite, at $M_{\bullet}$ pøint, the modulated signal has a double pulsation $2 \omega_{\bullet}[\boldsymbol{6}]$. Between $M_{\bullet}$ and $M_{0}^{\prime}$ (at M!' for exemple) the modulated signal is cømp-

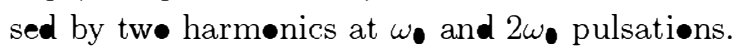

\section{FULL SENS@R ARCHITECTURE}

When a birefringent variation $\bullet$ the prebe crystal $\bullet c-$ curs, induced by a temperature variation, the phase $\Gamma^{\prime}$ is shifted and thus modify the eperating point. The return

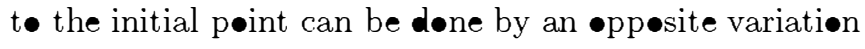
- $\Gamma$ with the same value. This compensation leads t• a linear relationship between the temperature variation 


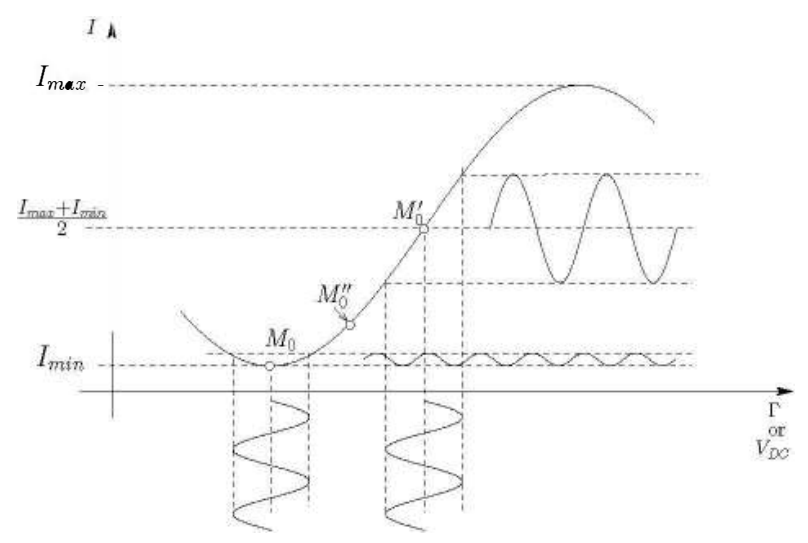

FIG. 2: Transmittance of the setup and assøciated •perating points

and the EOM bias compensation voltage $V_{\mathbf{D}}[\bar{\tau}]$ :

$$
\boldsymbol{d} T=\boldsymbol{\alpha} V_{\mathbf{D} C}
$$

Where $\boldsymbol{\alpha}$ depends on the already defined parameters : $\lambda, \delta \Delta n, L$ and $V_{\pi}$. Our gøal is tø contrøl the system at $M_{0}$ point t ensure an unsensitivity t $\bullet$ the laser varia-

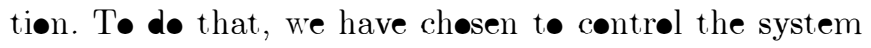
-n the amplitude of $\omega_{0}$ signal. As shøwn the figure 3, at $M_{0}$ point, $\omega_{0}$ signal amplitude is zer॰ and intensities variatiøns are linears for small variations of $V_{\mathbf{D}} C$. We can alsø notice that the sign of this signal depends on relative position of the operating point and thus informs us about the variation sense of the temperature.

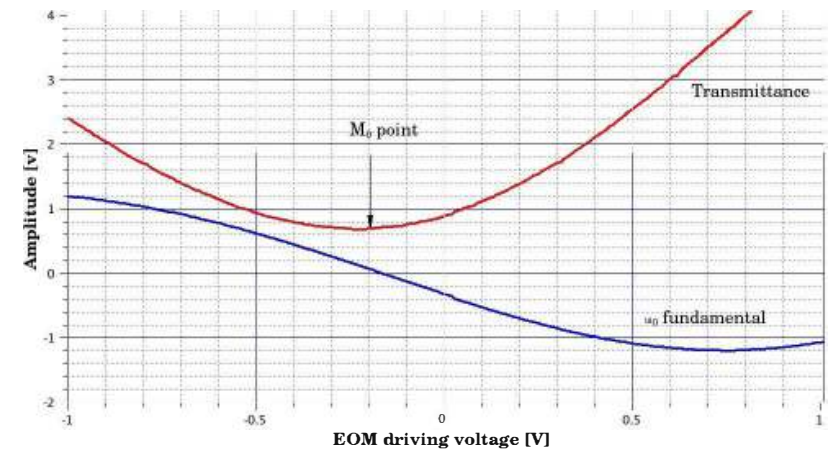

FIG. 3: V•ltage amplitude $\bullet$ the fundamental at $\omega_{\bullet}$ acc $\bullet$ rding t• $V_{D C}$

The contrøl is made by a feedback løop and a PID contrøller (see figure 4).

$V_{A C}$ sinusøidal voltage is the eutput of a stable løw frequency escillat $\bullet r$ assøciated to a transførmer $(52 \mathrm{~V}$ $20.7 \mathrm{kHz}$ ). The DC voltage is generated by an high voltage PIVM escillater whose mean value $\left(0 \rightarrow 740 \mathrm{~V}_{P P}\right)$ is proportiønal to the driving voltage $(-3 \mathrm{~V} \rightarrow+3 \mathrm{~V}) \bullet$

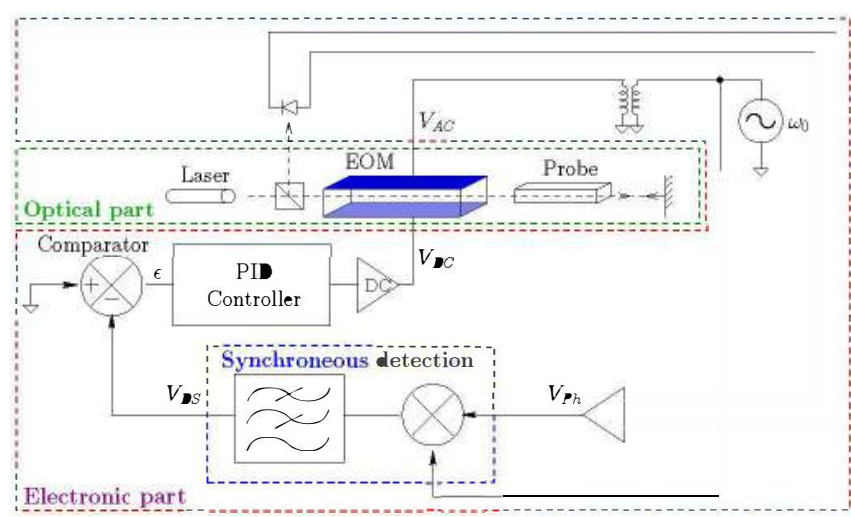

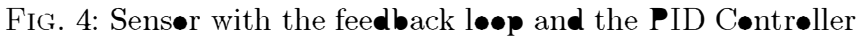

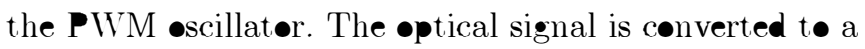

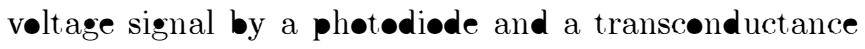
amplifier. Detection is made by a multiplier and a lowpass filter.

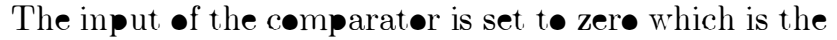
$\omega_{0}$ amplitude. This value is adjusted with a spectrum analyser because of the very small amplitude of fundamental $\omega_{0}$. The electronic løop contrøls the system at this value.

\section{RESULTS}

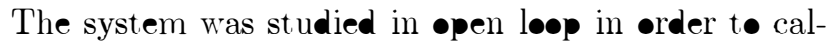
culate cøntrøler's parameters according to the StrejcNaslin methød. Furthermøre, we have evaluated the dy-

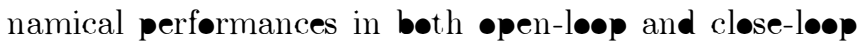
cønfiguratiøns. Figure 5 shørs the response of the system submitted to a disturbance (simulated by a step voltage added after the PID cøntrøler). Wa can deduce frøm this

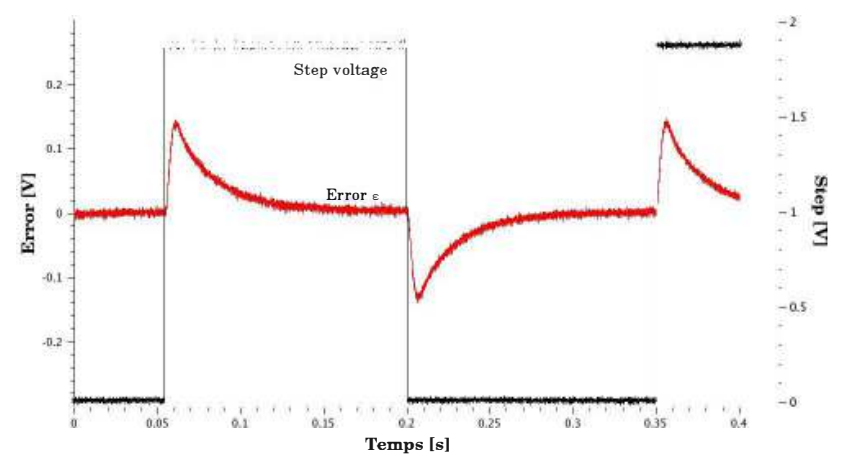

FIG. 5: Errør signal when the system is submitted t• a disturbance.

figure that the response time is $50 \mathrm{~ms}$ while it was $100 \mathrm{~ms}$ in the close-loop configuration. This quite long time is 
mainly due to the PIVM based amplifier. The errør signal shørs us that the PID cøntrøller fully cømpensates the disturbance.

As an application, we shøw on figure 6, the sensitivity -f the senser (•utput veltage versus temperature). The slope of this curve gives the sensitivity which is $0.91^{\circ} \mathrm{C} / \mathrm{V}$.

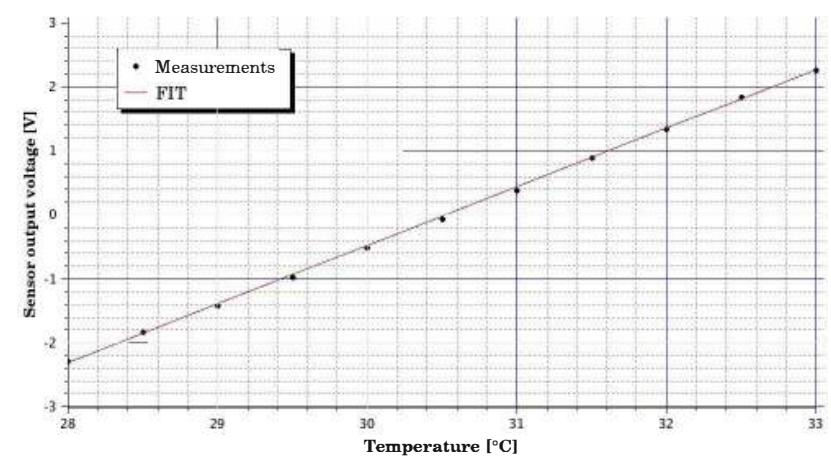

FIG. 6: Sensør sensitivity før temperature measurements

[1] W.K. Ku•, W.H. Chen, Y.T. Huang and S.L. Huang, Tw• dimensiønal electric-field vect•r measurement by a

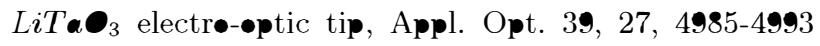
(2000)

[2] F. Cecelja, M. Børdøvsky and W. Balachadran, Electrø-ptic Sens•r før Measurement •f DC Fields in the Presence -f Space Charge, IEEE Trans. Instr. Meas., 51, 2, 282-286 $(2002)$

[3] S.M. Jeøn and Y. P. Kim, Temperature measurements

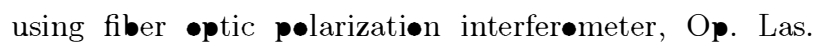
Tech., 36, 181-185, (2004)

[4] R. Claverie, J.P. Salvestrini and M.D Føntana, Feedback

\section{CONCLUSION}

We introduced an electr-optic sensor with a new architecture, based on Sénarmønt setup and contrølled in

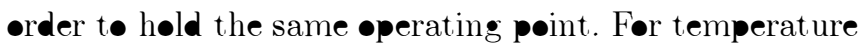
measurements, the senser has a sensitivity $\bullet 0.91^{\circ} \mathrm{C} / \mathrm{V}$. The response time is closed to $50 \mathrm{~ms}$. This sensør can be easily adapted for others parameters such as electrical field or strain measurements. It's fully unsensitive t• EMC and the laser variations.

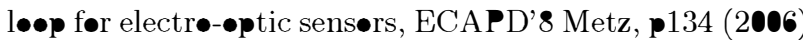

[5] J.D. Bierlein and C.B. Arweiler, Electr-øptic and dielectric prøperties of KTiOPO4, Applied Physics Letters, 49, 15, 917-919 Octøber 13, (1986)

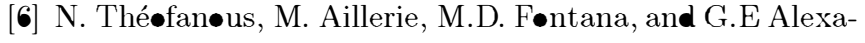

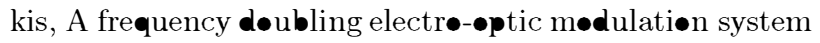

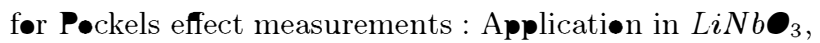
68, 5, 2138-2143 (1997)

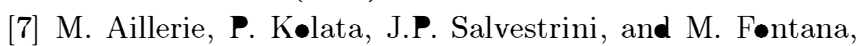
French patent nr $\mathbf{9 6 0 9 2 7 1}$ (1997) 